\title{
Impact of nutrition education on nutrition knowledge of public school educators in South Africa: A pilot study
}

\author{
Authors: \\ Wilna H. Oldewage-Theron ${ }^{1}$ \\ Abdulkadir Egal ${ }^{1}$ \\ Affiliations: \\ ${ }^{1}$ Centre of Sustainable \\ Livelihoods, Vaal University \\ of Technology, South Africa \\ Correspondence to: \\ Wilna Oldewage-Theron \\ Email: \\ wilna@vut.ac.za \\ Postal address: \\ Private Bag X021 \\ Vanderbijlpark 1900, \\ South Africa \\ Dates: \\ Received: 10 May 2011 \\ Accepted: 12 Apr. 2012 \\ Published: 31 July 2012 \\ How to cite this article: \\ Oldewage-Theron, W.H. \\ \& Egal, A., 2012, 'Impact \\ of nutrition education on \\ nutrition knowledge of public \\ school educators in South \\ Africa: A pilot study', Health \\ SA Gesondheid 17(1), Art. \\ \#602, 8 pages. http://dx.doi. \\ org/10.4102/hsag.v17i1.602
}

(C) 2012. The Authors.
The Department of Basic Education (DBE) has not given nutrition education the necessary emphasis that it needs, despite its importance in South African schools. Nutrition is included as only one of many topics forming part of the Life Orientation syllabus. Educators are role models for learners in making healthy food choices, however, studies have shown that major gaps exist in the health and nutrition-related knowledge and behaviour of educators.

The objective of this research was to undertake a pilot study to determine the impact of a nutrition education programme (NEP) on the nutrition knowledge of Life Orientation educators in public schools in South Africa (SA).

An exploratory baseline survey, to determine the nutrition education practices in 45 purposively selected public schools, was carried out before the experimental nutrition education intervention study. A nutrition knowledge questionnaire was completed by 24 purposively selected educators, representing all nine provinces in SA, before and after a three-day NEP. Pre and post-NEP data were analysed on the Statistical Package for Social Sciences (SPSS) for a Windows program version 17.0 for descriptive statistics, version 17.0. Paired t-tests measured statistically significant differences $(p<0.05)$ before and after the NEP.

The knowledge of the respondents improved significantly after the NEP as the mean \pm s.d. score of correctly answered questions $(n=59)$ improved from $63.3 \pm 30.2 \%$ before to $80.6 \pm 21.1 \%$ after the NEP.

The results proved that nutrition knowledge of Life Orientation educators in primary schools is not optimal, but can be improved by NEP.

Die Departement van Basiese Opvoeding het nog nie die nodige aandag aan voeding voorligting in skole gegee nie ten spyte van die belangrikheid daarvan. Voeding word aangebied as een van vele aspekte in die Lewensoriëntasie sillabusse. Onderwysers is rolmodelle om gesonde voedsel keuses te maak vir kinders, maar studies het bewys dat tekortkominge bestaan in die gesondheid en voeding verwante kennis en optrede van onderwysers.

Die doel van hierdie loods studies was om die impak van 'n voeding voorligting program op die voeding kennis van Lewensoriëntering onderwysers in publieke skole in Suid Afrika (SA) te bepaal.

'n Basislyn ondersoek was uitgevoer om die voeding praktyke van onderwysers uit 45 doelbewuste gekose publieke skole te bepaal voor en na die implementering van ' $n$ eksperimentele voeding voorligting intervensie studie. ' $n$ Voeding kennis vraelys is deur 24 doelbewuste gekose onderwysers, verteenwoordigend van al nege provinsies in SA, voltooi voor en na die drie-dag voeding voorligtingsprogram. Beide pre en post data is geanaliseer op die Statistical Package for Social Sciences (SPSS) vir Windows program, uitgawe 17.0, vir beskrywende statistieke. Gepaarde t-toetse is gebruik om statisties betekenisvolle verskille $(p<0.05)$ voor en na die intervensie te bepaal.

Die kennis van die respondent het betekenisvol verbeter na die intervensie aangesien die gemiddelde \pm s.d. uitslag van die vrae wat korrek geantwoord is $(n=59)$ van $63.3 \pm 30.2$ persent voor tot $80.6 \pm 21.1$ persent na die intervensie verbeter het.

Die resultate het bewys dat die voeding kennis van Lewensoriëntering onderwysers in publieke skole in SA nie optimaal is nie, maar dat dit kan verbeter deur voeding voorligtingsprogramme.

\section{Introduction}

\section{Problem statement}

In South Africa (SA) the conditions of being stunted and underweight remain the most common nutritional disorders amongst children, with a prevalence of $20 \%$ and $10 \%$ respectively. 
Nationally, however, $10 \%$ of children are overweight and $4 \%$ are obese. Furthermore, $66.7 \%$ of all children in SA have a poor vitamin A status and one out of seven children has a poor iron status with $33.3 \%$ being anaemic. Nationally, $45.3 \%$ of children have an inadequate zinc status (Labadarios et al. 2008:255, 261, 262, 264). Children in SA are, thus, faced with multiple malnutrition problems, such as over and under nutrition, including micronutrient deficiencies.

\section{Background}

Poor nutrition knowledge is one of the main factors in the development of malnutrition and needs to be addressed (Briggs, Fleschhacker \& Mueller 2010:361). One of the factors influencing nutritional status is a lack of education and nutritional knowledge. Other factors are inappropriate nutrition education, misconceptions and passing on of harmful diet traditions and poor nutritional practices passed from parents to children (Vorster, Love \& Browne 2001:S6). Health and nutrition education can, thus, play an important role in addressing malnutrition. During their school years, children develop major cognitive, physical and social skills. The cognitive maturity level of a child particularly influences his or her ability to gain from nutrition education. Research has proved that a behaviourally focused approach with active methods, including food-based activities, will enhance the effectiveness of nutrition education programmes and, thus, the nutrition knowledge of children (Contento 2007:441).

\section{Trends}

One of the most effective ways to change behaviour is an early intervention programme that promotes healthy eating and an active lifestyle (Sharma, Gernand \& Day 2008:362). There is, therefore, an urgent need for the promotion of effective health and nutrition education interventions to implement changes in food choice, diet and lifestyle (Brug 2004:43).

Schools are in an excellent position to promote healthy eating, as most children spend most of their time at school. Moreover, school-based nutrition education is ideal as children can be engaged in healthy eating and physical activity programmes that reinforce the messages of nutrition education (Briggs et al. 2010:361; Gross \& Cinelli 2004:793). Children are also effective change agents, transferring what they learn at school to the communities they live in. Providing children with nutrition education in schools is, therefore, an effective investment that should be supported by governments and funding agents, as this can address the nutritional problems of communities over the short and long term (David, Kimiywe, Waudo \& Orodho 2008:131). Despite the importance of nutrition education in schools, the Department of Basic Education (DBE) has not given it the necessary emphasis in schools in SA, as nutrition is included as only one of many topics forming part of the Life Orientation syllabus.

Educators should function as role models for their learners by making healthy food choices of their own (Roberts, Pobocik, Deek, Besgrove \& Prostine 2009:297). However, it is doubtful whether or not educators are equipped to deliver the appropriate health and nutrition messages (Chen, Ceh, Lai, Shyu, Huang \& Chiou 2010:579), as studies have shown that major gaps exist in their health and nutrition-related knowledge and behaviour (Shah, Adams-Huet, Elston, Hubbard \& Carson 2010:427).

\section{Research objective}

The main objective of this pilot study was to determine the impact of a nutrition education training programme (NEP) on the nutrition knowledge of Life Orientation educators in public schools in SA.

\section{Contribution to the field}

This was a pilot study and is the first study reporting on the impact of nutrition education on the nutrition knowledge of Life Orientation educators in primary schools in SA.

\section{Research method and design}

This study was undertaken in two phases, namely the baseline survey and the pilot study that were a nutrition education intervention, including pre and post evaluation measurements.

\section{Design}

An exploratory baseline survey to determine the nutrition education practices in 45 purposively selected public schools was carried out before the experimental intervention study. The baseline sample consisted of Life Orientation educators and principals $(n=90)$ of 45 purposively selected primary schools, including urban, peri-urban and rural schools, from all nine provinces.

The baseline results were established to determine the content of the nutrition education manuals to be used in the intervention. The intervention study was an experimental study and the following power calculation (Gibson 2006:6) was used to determine the sample size for a representative sample: - $n=\frac{2 \mathrm{X}(\mathrm{u}+\mathrm{v})^{2}}{\mathrm{E}^{2}} \underline{\underline{\mathrm{X}} \mathrm{s}^{2}}$

- Where $\mathrm{u}=0.67 \mathrm{~m}$ corresponding to $\mathrm{a} \beta$ for the test of $75 \%$ power

- $\mathrm{v}=1.647$ corresponding to a significance level of $10 \%$ for a two-tailed hypothesis

- $\quad \mathrm{E}=$ the expected mean change in knowledge, set at $30 \%$ for this study

- $\quad \mathrm{s}=$ the standard deviation of the change in the nutrition knowledge, assumed to be 4.4 for this study (range of 0.44-0.64 (Oldewage-Theron \& Egal 2009:49).

A total of 23 respondents were required in order to obtain statistically representative data for this study. The sample, thus, included a purposive sample of 24 urban, peri-urban 
and rural Life Orientation educators and district managers, identified by the DBE and representing all nine provinces in SA. All of the educators attended the training in the pilot study (intervention) voluntarily.

\section{Materials}

For the purpose of the baseline survey, a multiple-choice questionnaire was drawn up by the researchers to determine:

- current nutrition education practices

- nutrition education tools and textbooks available and needed

- nutrition education topics to be included in the DBE Life Orientation syllabus.

The measuring instrument for the intervention study was a multiple-choice nutrition knowledge questionnaire consisting of 59 questions developed by the researchers, for the purpose of this study and tested for internal validity $(\alpha=0.73)$. The questionnaire was completed by the educators themselves before and directly after the NEP. Pre and post-intervention data were captured from the knowledge questionnaires on an Excel spreadsheet.

\section{Data collection methods}

The methods followed, for the development of the nutrition education manuals, included the respective phases as determined by the United Nations Food and Agriculture Organisation (FAO) in 1998 for the development and implementation of nutrition education programmes, as indicated in Figure 1.

During Phase 1, a baseline survey was conducted to determine the problem and content of the nutrition education manuals. The methods for the baseline survey included school visits to the 45 selected schools. Two postgraduate students were trained as fieldworkers and assisted the researchers with data collection. The questionnaire was completed through one-on-one interviews with the participating educators. The results were used to establish the problem. A meeting was held with the FAO (funding agency) and DBE stakeholders to discuss the content and format of the nutrition education

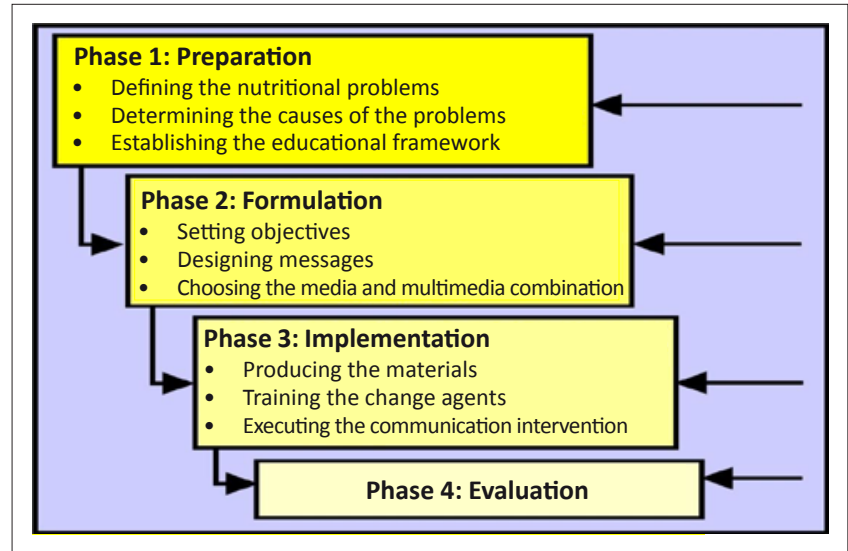

FIGURE 1: FAO framework for nutrition education (FAO 1998). manuals, based on the baseline survey results (establishing the educational framework).

During Phase 2 (formulation phase), a literature search followed, during which the latest information was obtained on all the topics that were agreed upon. The text of the manuals was written, after which the content was checked by a registered dietitian for correctness. A language editor was contracted to check the text for correct use of English and South African spelling.

After the language editing, the documents were sent to two graphic designers who developed the illustrations, page layout and design. The manuals were proofread and draft manuals were printed and delivered to the FAO and DBE for recommendations. After minor changes had been made, the manuals were sent back to the graphic designers for finalisation and printing of 30 manuals to be distributed for the pilot study (intervention).

The intervention study entailed nutrition education training, scheduled over a period of three days, for eight hours each day. The topics included:

- Basic nutrition, including the role of nutrition in health, foods and nutrient composition.

- Nutritional concerns, including factors contributing to malnutrition (UNICEF framework), the definition of malnutrition, signs of malnutrition, as well as the consequences of malnutrition.

- Healthy eating habits for children, including what a good diet constitutes, dietary needs of children, the South African food-based dietary guidelines (FBDG), meal planning, and food portion sizes.

- Food security, including the global definition of food security, the concept of food security in SA, household food security, nutrition security, and strategies to promote national and household food security.

- Food safety and hygiene, including safe and unsafe food and water, food-borne diseases, and preventing the contamination of food and water.

- Hygiene, including a definition of hygiene, environmental hygiene, oral and dental health, and personal hygiene.

- Exercise and its relation to nutrition.

Each of the participants received a file containing the notes for the nutrition education training programme. The training was undertaken by means of lectures and group discussions. A question-and-answer session followed each of the topics covered and a 15-minute break was allowed between topics.

\section{Data analysis}

The baseline survey data were captured, cleaned and analysed for descriptive (frequencies) statistical analyses on the Statistical Package for Social Sciences (SPSS) program, version 17.0.

The results of the exploratory baseline survey were consulted to develop nutrition education manuals for the primary 
schools in SA. These manuals were introduced to a small sample of educators as part of an NEP pilot study, hereafter called the intervention study, before their revision and rollout in all of the provinces.

SPSS for Windows, version 17.0 was used to analyse the data for descriptive statistics, and paired t-tests were carried out to measure the statistically significant differences $(p<0.05)$ before and after the intervention. A self-administered workshop evaluation questionnaire, with six questions pertaining to the NEP, was also completed by the respondents on completion of the NEP. These data were also captured, cleaned and analysed using SPSS, version 17.0 for descriptive statistics (frequencies).

\section{Context of the study}

The DBE in SA gave permission to undertake the baseline survey in 45 purposively selected public schools chosen by the DBE. These schools represented all nine provinces of SA.

The nutrition education training intervention was held at a conference venue in Gauteng. The educators, taking part in the pilot study, represented all nine provinces of SA and attended the training at the conference venue.

\section{Results}

\section{Exploratory baseline results}

A total of 90 educators and principals from 45 schools, representing all nine provinces in SA, completed the questionnaires for the baseline survey. The results showed that nutrition education mainly formed part of the Life Orientation syllabus $(97.8 \%)$, with $2.2 \%$ also included in Natural Science. The results further indicated that the majority of the schools included nutrition education in all Grades (0 to 12), ranging from $68.9 \%$ in Grade 0 to $95.6 \%$ in Grade 8. The majority of the schools (60.0\%) spent less than one hour per week on nutrition education, with a small percentage $(20.0 \%)$ spending more than two hours per week on the subject.

The results in Table 1 indicated the nutrition education tools that the educators had available at the school. The results showed that the majority of schools (95.6\%) had textbooks available for nutrition education, but only $24.4 \%$ of nutrition education was offered through formal lectures. Although $44.8 \%$ indicated the use of food models and $26.7 \%$ the use of food puzzles, these results are doubted as food models, and puzzles are not readily available in SA and have to be imported from the United States of America at enormous cost (R6 800 for 50 food models in 2005). The same is true for the nutrition education games and cards used by a small number of schools ( $11.1 \%$ and $6.7 \%$ respectively).

The results in Table 2 indicated that the educators obtained their nutrition knowledge mainly from textbooks $(88.9 \%)$, seminars (77.8\%) and local television programmes (73.3\%).
In Table 3, the topics currently covered in nutrition education are indicated. The results show that the majority of schools already included most of these recommended topics. However, only a few schools $(n=8,17.8 \%)$ included the World Health Organisation (WHO) growth standards. Food security is also a topic covered in few schools, as only $28.9 \%$ indicated that the causes of food security, and strategies to combat food insecurity at community level (31.1\%), were included in nutrition education. The majority of the respondents $(97.8 \%)$ indicated that the topics covered in the Life Orientation syllabus were sufficient and should not be expanded, but agreed that a need existed for nutrition education in schools (97.8\%). Ninety-one percent of the respondents suggested that primary school children, as well as parents $(86.7 \%)$, educators $(82.2 \%)$ and the National School Nutrition Programme (NSNP) volunteers (80.0\%), should receive nutrition education.

The results showed that the nutrition education materials and tools needed by most of the respondents were colouring books $(71.1 \%)$, videos $(71.1 \%)$, posters and wall charts $(60.0 \%)$ and nutrition education card games (51.1\%). These should be available in bright colours (95.5\%), with either photographs $(62.2 \%)$ or colour drawings $(62.2 \%)$ included to illustrate the text, and these should preferably be produced in both English and the local language (75.6\%).

\section{Intervention results}

The results of the baseline survey were used to determine the content of the nutrition education manuals. It was

TABLE 1: Top six nutrition education tools available and methods used for nutrition education by the schools.

\begin{tabular}{lll}
\hline Tools & $\boldsymbol{N}$ & $\mathbf{\%}$ \\
\hline Textbook & 43 & 95.6 \\
Pamphlets & 31 & 68.9 \\
Food models, including actual food items & 22 & 48.8 \\
Food puzzles & 12 & 26.7 \\
Lectures & 11 & 24.4 \\
Nutrition education games & 5 & 11.1 \\
\hline
\end{tabular}

$N$, Number of schools.

TABLE 2: Six most available sources of nutrition education information.

\begin{tabular}{lll}
\hline Sources & $(N=90)$ & $\mathbf{\%}$ \\
\hline Textbooks & 80 & 88.9 \\
Seminars & 70 & 77.8 \\
Television & 66 & 73.3 \\
Magazines & 62 & 68.9 \\
Colleagues & 56 & 62.2 \\
Local clinic & 56 & 62.2 \\
\hline
\end{tabular}

$N$, Number of participants.

TABLE 3: Top six nutrition education topics covered.

\begin{tabular}{lll}
\hline Topics & $\boldsymbol{N}$ & $\mathbf{\%}$ \\
\hline Healthy food choices & 40 & 88.9 \\
Food and nutrient composition of foods & 40 & 88.9 \\
Diseases of lifestyle & 39 & 86.7 \\
Factors contributing to malnutrition & 39 & 86.7 \\
Role of nutrition in health & 38 & 84.4 \\
Signs of malnutrition & 38 & 84.4 \\
\hline
\end{tabular}

$N$, Number of schools. 
decided too, by all of the stakeholders, that the tool for nutrition education should be a nutrition education manual, as textbooks were the most preferred and used nutrition education tool in all of the schools. The content included all of the nutrition related topics that were already covered in the syllabi of the schools (Refer to Table 3), as well as those that were not covered, such as food safety and hygiene, the dietary needs of children, and meal planning, to name a few of these topics.

There was a $100 \%$ attendance rate $(n=24)$ at the workshop training sessions. The results of the NEP evaluation questionnaire indicated that the workshop was well organised, and that the topics covered were considered, by the majority of respondents, to be appropriate in depth and scope and applicable to the classroom situation.

In general, before the NEP, $5.3 \%, 63.1 \%$ and $31.6 \%$ of the respondents indicated that they had very good, good and fair nutrition knowledge respectively (Table 4). No respondents rated themselves as having excellent and poor nutrition knowledge, before the education from the NEP. This improved after the NEP to $5.3 \%(p=0.331), 47.4 \%(p=0.002)$, and $47.4 \%(p=0.331)$, of the respondents rating themselves as having excellent, very good and good nutrition knowledge respectively. None of the respondents indicated fair or poor nutrition knowledge after the intervention, compared to $31.6 \%$ ( $p=0.010)$ and $0.0 \%$ before the intervention respectively.

The results in Table 5 and 6 are reported as percentages of correct answers for each question as asked in the questionnaire. The majority of the respondents knew, before $(94.7 \%)$ and after $(100.0 \%)$ the NEP, that breakfast is the most important meal of the day for children. The majority of the respondents could identify the components of foods, such as carbohydrates, fat, protein, minerals and vitamins

TABLE 4: Percentage of respondents rating their nutrition knowledge before and after the intervention $(n=24)$.

\begin{tabular}{|c|c|c|c|}
\hline \multirow[t]{2}{*}{ Level of nutrition knowledge } & Before & After & Significance \\
\hline & $\%$ & $\%$ & $p$ \\
\hline Excellent & 0.0 & 5.3 & 0.331 \\
\hline Very good & 5.3 & 47.4 & 0.002 \\
\hline Good & 63.1 & 47.4 & 0.331 \\
\hline Fair & 31.6 & 0.0 & 0.010 \\
\hline Poor and/or bad & 0.0 & 0.0 & - \\
\hline
\end{tabular}

$p$, significance.

TABLE 5: Percentage of correct answers to questions regarding the classification of nutrients.

\begin{tabular}{lccccc}
\hline Nutrient & Before & & After & & Significance \\
\cline { 2 - 2 } \cline { 5 - 5 } \cline { 5 - 5 } & $\mathbf{\%}$ & & $\mathbf{\%}$ & \\
\hline Fat & 47.1 & & 94.7 & \\
Minerals & 73.7 & & 84.2 & & 0.001 \\
Protein & 94.7 & & 89.5 & & 0.429 \\
Carbohydrates & 68.4 & & 89.5 & & 1.000 \\
Water & 52.6 & & 84.2 & & 0.268 \\
Vitamins & 52.6 & & 89.5 & & 0.015 \\
Mean \pm s.d. score & $64.9 \pm 17.8$ & & $88.6 \pm 4.0$ & & 0.028 \\
\hline
\end{tabular}

$p$, significance. correctly before $(64.9 \pm 17.8 \%)$ the intervention, and this improved significantly $(p=0.028)$ after $(88.6 \pm 4.0 \%)$ the intervention. However, the classification of the components into micronutrients and macronutrients was not as well known by the respondents before the intervention, specifically with regard to the classification of fat $(47.1 \%)$, water $(52.6 \%)$ and vitamins $(52.6 \%)$. The NEP resulted in a significant improvement in knowledge, as $94.7 \%$ and $89.5 \%$ of the respondents could correctly classify fat $(p=0.001)$ and vitamins $(p=0.015)$ after the NEP respectively (Table 5).

The main functions of protein (maintenance and building of body mass), carbohydrate (providing energy), calcium (maintenance and building strong bones and teeth), dietary fibre (healthy bowel movements) and water (transportation of nutrients and waste products) were known to the respondents, as $73.7 \%, 63.2 \%, 94.7 \%, 57.9 \%$ and $89.5 \%$ respectively answered the questions correctly before the NEP. Before the training, knowledge of the functions of the individual micronutrients, such as vitamins D, A, K, $\mathrm{C}$, as well as iron and zinc, was poor and did not improve significantly after the training. However, the mean score for all questions pertaining to the functions of the nutrients improved significantly ( $p=0.001$ ) from $46.2 \pm 32.6 \%$ before to $59.9 \pm 27.5 \%$ after the intervention.

Malnutrition could not be defined before the NEP as only $21.1 \%$ of the respondents knew the meaning of malnutrition, including under and over-nutrition. This improved significantly ( $p=0.002$ ) to $73.7 \%$ after the NEP. The causes of malnutrition were not well known before the intervention but improved considerably as the scores ranged between $47.4 \%$ and $100 \%$ before the NEP to between $84.4 \%$ and $100.0 \%$ after the NEP. The majority of the respondents did not identify disease as a cause of malnutrition, although the consequences of malnutrition could be identified by the majority of the respondents before (78.9-100.0\%) and after the NEP (89.5-100.0\%). It can be concluded that although the majority of the respondents could not define malnutrition before the intervention, they had a fairly good knowledge of malnutrition as the mean \pm s.d. score for all the questions pertaining to malnutrition that were correctly answered. These figures were $74.7 \pm 19.5 \%$ before the intervention compared to $85.3 \pm 21.4 \%$ after the intervention $(p=0.103)$.

Fortification was a little-known concept, as only $31.6 \%$ of the respondents knew the meaning of fortification and 52.6\% could identify maize and bread as being fortified products, although $73.7 \%$ had seen the fortification logo before the NEP. After the NEP, $89.5 \%$ of the respondents knew the meaning of fortification and $84.2 \%$ correctly identified maize and bread as being fortified food products in SA. The mean \pm s.d. score for all the questions pertaining to fortification, that were correctly answered, was $52.6 \pm 21.1 \%$ before the intervention and this improved to $91.2 \pm 8.04 \%$ after the intervention, however, this improvement was not significant $(p=0.059)$. 
TABLE 6: Percentage of correct answers pertaining to malnutrition before and after the intervention.

\begin{tabular}{|c|c|c|c|}
\hline \multirow[t]{2}{*}{ Malnutrition parameters } & Before & After & Significance \\
\hline & $\%$ & $\%$ & $p$ \\
\hline Definition of malnutrition & 21.1 & 73.7 & 0.002 \\
\hline \multicolumn{4}{|l|}{ Possible cause of malnutrition } \\
\hline Disease & 47.4 & 47.4 & 0.002 \\
\hline Insufficient health services & 73.7 & 84.4 & 0.187 \\
\hline Household food insecurity & 84.2 & 94.7 & 0.331 \\
\hline Inadequate dietary intake & 100 & 100 & 1.000 \\
\hline Inadequate education & 68.4 & 94.7 & 0.056 \\
\hline \multicolumn{4}{|c|}{ Possible disadvantages of malnutrition } \\
\hline Fatigue & 100 & 100 & 1.000 \\
\hline Poor school performance & 100 & 100 & 1.000 \\
\hline Irritability & 78.9 & 89.5 & 0.331 \\
\hline Poor memory & 100 & 100 & 1.000 \\
\hline Frequent absences from school & 78.9 & 100 & 0.042 \\
\hline
\end{tabular}

$p$, significance.

Although $26.3 \%$ of the respondents had heard of the FBDG before the training, $100.0 \%$ could not name any of the FBDG. After the NEP, $57.9 \%$ of the respondents could correctly cite the eleven FBDG. Before the intervention, $63.2 \%$ understood the meaning of 'enjoy a variety of foods' and $42.1 \% \mathrm{knew}$ what was meant by a 'balanced, mixed meal'. This improved significantly to $84.2 \%$ and $100.0 \%$ respectively after the NEP. The meaning of the FBDG, that 'chicken, fish, meat, milk or eggs can be eaten daily' was well understood by the majority of the respondents $(94.7 \%)$ before the NEP. The same was found for the FBDG before the intervention:

- 'eat plenty of vegetables and fruits every day' (94.7\%)

- 'be active' (84.2\%)

- 'drink lots of clean, safe water' (100.0\%)

- 'use food and drinks containing sugar sparingly and not between meals' (100.0\%).

The knowledge of the FBDG did not improve significantly after the NEP $(p>0.05)$.

The respondents had poor knowledge of food security before the NEP, but this improved significantly $(p=0.003)$ from a score of $31.6 \%$ to $63.2 \%$ after the NEP. Regarding food safety, only $5.6 \%$ of the respondents could identify any safe foodhandling principles, compared with $47.4 \%$ after the NEP. The majority of the respondents were well aware of the importance of the washing of fruit and hands before eating, as $84.2 \%$ and $100.0 \%$ respectively answered the questions correctly before the NEP.

In general, the knowledge of the respondents improved significantly ( $p=0.047$ ) after the NEP, as the mean \pm s.d. score of correctly answered questions $(n=59)$ by all the respondents $(n=24)$ increased from $63.3 \pm 30.2 \%$ to $80.6 \pm 21.1 \%$.

\section{Ethical considerations}

This study was conducted according to the guidelines laid down by the South African Medical Research Council and the Declaration of Helsinki, and all the procedures involving the human respondents were approved by the university research ethics committee and the DBE head office.

\section{Potential benefits and hazards}

Only questionnaires, and no other content, were completed by the respondents, and no risk or hazards were involved. The benefits of the study were that the respondents were made aware of the shortcomings in their nutrition knowledge and perceptions thereof, and this could lead to the respondents studying these shortcomings in order to translate this knowledge more effectively in the teaching materials in schools. Furthermore, the results of this study should provide the DBE with the necessary information on what to include in future short courses and training programmes of Life Orientation educators.

\section{Recruitment procedures}

The DBE invited Life Orientation educators from the various districts and provinces to participate in this pilot study. This was, thus, a purposive sample of the educators responding to the DBE invitation.

\section{Informed consent}

Verbal consent was obtained from the respondents and recorded before the nutrition knowledge assessment. No written consent was obtained as no private information about the respondents was taken, no invasive procedures were administered, nor were anthropometric, biochemical or blood measurements collected.

\section{Data protection}

All respondents were allocated a study number and only these were indicated on all of the questionnaires. The school, district, province or name of the individual could not be traced should a questionnaire be found by anybody, as no personal information was required for this study.

\section{Validity and reliability}

The reliability of the questionnaire was tested in a school not participating in the study. Each week, for a period of four weeks, the same ten randomly selected educators completed the questionnaire. The answers were compared by means of Cronnbach-Alpha analyses. Based on the results the questionnaire was accepted as reliable (mean $\alpha=0.73$ ). In addition, factor analyses were carried out to unmask possible outliers in the reliability test.

\section{Discussion Outline of the results}

The objective of this pilot study was to determine the impact of a NEP on the nutrition knowledge of Life Orientation educators in public schools in SA.

Food insecurity and hunger are leading causes of malnutrition and poor health in many African countries, but these are not the only causes of malnutrition, as other factors such as ignorance and illiteracy may also impact on malnutrition. A healthy choice of food is the key to 
well-being and to the prevention of many of these dietary problems. Dietary recommendations, based on scientific evidence, provide guidance to consumers and health care professionals in choosing and planning a healthy diet, but the growing incidence of malnutrition indicates that there is a gap between the dietary recommendations and nutrient intake behaviour (Kris-Etherton 2004:18). Nutrition education is the vehicle by means of which people, including children, can improve their nutrition knowledge and gain the skills needed for developing good dietary habits (David et al. 2008:131). School may be the only place where school children can learn about healthy eating habits and acquire lifelong skills that are essential, in later life, to ensure economic security and high levels of physical, mental and social well-being (Marks 2009:7). Because of this, educators in schools should be fully equipped to assist the learners to learn healthy eating habits. Nutrition education is also an effective way of fighting hunger, malnutrition and poor health and is more sustainable than food aid (David et al. 2008:137). Results from the baseline survey indicated that although nutrition education was offered in the majority of the primary schools observed, and to the learners in all of the Grades, not much time per week was allocated to this subject. This was consistent with studies in America, where it was found that health and nutrition education is not considered equally important to other subjects, when the school curriculum is being planned (Marks 2009:6). Although the respondents indicated that the nutrition syllabus was sufficient regarding the topics included, there are, nevertheless, still gaps in the syllabus, such as food security and the identification of malnourished children. However, the educators did not indicate a need to include these topics in the Life Orientation syllabus. The educators indicated a need for nutrition education for learners, their caregivers, educators and the NSNP volunteers. This was consistent with the findings by Marks (2009:6), that standalone classroom NEP is not sufficient to influence the eating habits of children, and that all stakeholders, including the educators and child caregivers, should be involved.

There is a strong relationship between the knowledge and training received by an educator and their ability to teach this subject matter. Research has found that educators spend more time on subject matter in which they have been trained appropriately (Myers \& Pope 2009:13-14). The educators participating in this pilot study indicated average-to-poor knowledge of nutrition before the NEP and, therefore, a lack of confidence in presenting nutrition to the learners as part of the Life Orientation syllabus. Most of the educators in this study relied on textbooks (88.9\%), seminars (77.8\%), television $(73.3 \%)$ and magazines (68.9\%) for nutrition knowledge, and only $33.3 \%$ and $26.7 \%$ received nutrition education when studying, and as part of in-service learning respectively. Other studies further found that educators lack confidence in teaching topics in which they do not have sufficient knowledge (Lumeng, Kaplan-Saroff, Shurman \& Kannan
2008:242). In this study, this was proved by the fact that Life Orientation was offered for less than one hour per week in the majority of the schools. Nutrition is one of the many life skills offered in the Life Orientation syllabus and is, thus, much less prevalent in SA schools than the total number of 50 hours nutrition education recommended as the minimum number of hours required to facilitate behavioural change in children (Briggs et al. 2010:363). Lack of training and support for educators is just one of the many obstacles that educators face when implementing school wellness programmes and syllabi. Other factors include proper guidelines, time constraints, other academic priorities, funding and low levels of educator participation.

\section{Practical implications}

Educators are key actors in the facilitation and articulation of theory to practice (Yokota, de Vasconcelos, Pine, Schmitz, Coitinho \& Rodrigues 2010:38), not only in Life Orientation, but in all the subjects presented at school. There is a need, therefore, for educator training in nutrition and health (Henry, White, Smith \& LeDang 2010:2), as nutrition education for educators and all the other social actors, including the learners and their caregivers, influences the school environment. The changes, thus, effected by nutrition education may include adopting healthy eating habits (Marks 2009:4; Yokota et al. 2010:38). A healthy diet is one of the most important components of a healthy lifestyle. The same is true for increasing the nutrition knowledge of members of lowincome families (Dammann \& Smith 2009:250).

Effective training should, moreover, be continuous and inter-disciplinary and should also be afforded sufficient time. To be effective in changing behaviour, nutrition education programmes should provide sequential training instead of occasional programmes on single topics, as has been found by a number of studies (Briggs et al. 2010:363; Marks 2009:4-5). Furthermore, NEP for educators should result in more comprehensible classroom instruction that will be more readily applied. NEP should improve not only the knowledge of the educators, but also their interest in nutrition, resulting in a better attitude and more time spent on nutrition education in the classroom (Briggs et al. 2010:363; Myers \& Pope 2009:14).

\section{Limitations}

The propensity for this study to be generalised is limited by:

- the small sample size

- the fact that convenience sampling was applied and some self-selection may have occurred

- the fact that in the power calculation a change of $30 \%$ in knowledge was hypothesised, compared with the $16.3 \%$ change achieved, despite the slightly lower s.d. (0.21-0.30) achieved in the results.

However, this was a pilot study and the exploratory results revealed that action is required, such as educator training, for successful implementation. It also provides a basis for 
more research, specifically, designing and implementing effective, evidence-based training intervention programmes to support the educators who have a direct influence on children's education and behaviour.

\section{Recommendations}

Two major implications may be drawn from this study. Firstly, educators need training, specifically related to nutrition education, and that a variety of resources in different formats should be provided to assist the educators in the classroom. Secondly, educators need effective strategies for communicating the nutrition education messages as a means to developing a healthy body and forming life-long healthy eating habits. This will be applicable not only to the learners, but also to their caregivers. Effective and helpful interventions are, thus, needed to address the needs of the educators who support both the children (directly) and their caregivers (indirectly) in developing healthy eating habits through nutrition education in schools. Similar findings were observed by Fees, Trost, Bopp and Dzewaltowski (2009:272). Although conventional methods of NEP, through lectures for example, can improve the knowledge of educators, more research is needed to identify how this knowledge is practically applied every day (Tessier, Chauliac \& Latcha 2010:229).

Further investigation of larger samples is needed to determine the nutrition knowledge of Life Orientation educators, their views on nutrition education in schools (Henry et al. 2010:7) and how educators correlate nutrition with relevant subjects, like biology. It is clear that few resources exist in the classroom and that nutrition professionals and the material they can develop may be a helpful resource for classroom educators (Henry et al. 2010:7; Myers \& Pope 2009:21).

\section{Conclusions}

The results of this study proved that the nutrition knowledge of Life Orientation educators in schools of SA is not optimal, but can be improved by an NEP. This is consistent with other studies where not only the knowledge, but also the educators' attitudes, improved after the implementation of an NEP (Lee, McDonnell \& Probart 1998:A42).

\section{Acknowledgements}

The authors hereby thank the DBE for allowing this study to be conducted and the educators for participating in this project. The fieldworkers, Joy Senoelo and Kuda Maruma, are also acknowledged. The project was funded by the United Nations Food and Agriculture Organisation (FAO).

\section{Competing interests}

There is no conflict of interest in this study.

\section{Authors' contributions}

Both authors were the principal investigators of this study. W.H.O-T. (Vaal University of Technology) was responsible for the study design and protocol and A.E. (Vaal University of Technology) was responsible for data management (data capturing, screening and analyses). Both authors were involved in the implementation and data collection as well as writing the manuscript.

\section{References}

Briggs, M., Fleschhacker, S. \& Mueller, C.G., 2010, 'Position of the American Dietetic Association, School Nutrition Association, and Society for Nutrition Education: Comprehensive School Nutrition Services', Journal of Nutrition Education and Behaviour 42(6), 360-371.

Brug, H., 2004, 'Changing consumer behaviour from a health promotion perspective: barriers and triggers'. In: Unilever. The healthy choice, an easy choice. Vlaardingen, The Netherlands: Unilever Health Institute, p 43-46.

Chen, Y.H., Ceh, C.Y., Lai, Y.M., Shyu, M.L., Huang, K.C. \& Chiou, H.Y., 2010 'Significant effects of implementation of health-promoting schools on school educators' nutrition knowledge and dietary intake in Taiwan', Public Health Nutrition 13(4), 579-588. http://dx.doi.org/10.1017/S1368980009991017, PMid:19656439

Contento, I.R., 2007, Nutrition education. Linking research, theory and practice, Jones and Bartlett Publishers, Sudbury, Massachusetts.

Dammann, K.W. \& Smith, C.S., 2009, 'Factors affecting low-income women's food choices and the perceived impact of dietary intake and socioeconomic status on their health and weight', Journal of Nutrition Education and Behaviour, 41(4), 242-253.

David, D.M., Kimiywe, J.O., Waudo, J.N. \& Orodho, J.A., 2008, 'Promotion of nutrition education interventions in rural and urban primary schools in Machakos District', Kenya. J Applied Biosciences 6,130-139.

Fees, B., Trost, S., Bopp, M. \& Dzewaltowski, D,A., 2009, 'Physical activity programming in family child care homes: providers' perceptions of practices and barriers', Journal of Nutrition Education and Behaviour 41(4), 268-273.

Food and Agriculture Organisation of the United Nations (FAO), 1998, The right to food in theory and practice, Publishing Management Group, FAO Information Division, Rome, Italy.

Gibson, R., 2006, Dietary methodology. Presentation at: Three-day Nutrition Society South Africa workshop, North-West University, Potchefstroom on 12-14 September 2006.

Gross, S.M., Cinelli, B., 2004, 'Coordinated school health program and dietetics professionals: partners in promoting healthful eating', Journal of the American Dietetic Association 104(5), 793-798. http://dx.doi.org/10.1017/ S1368980009991017, PMid:19656439.

Henry, B.W., White, N.J., Smith, T.J. \& LeDang, L.T., 2010, An exploratory look at educator perceptions of school food environment and wellness policies. Infant, child and adolescent nutrition, viewed 31 January 2011, from http://can.sagepub. com/content/early/2010/08/25/1941406410382577

Kris-Etherton, P.M., 2004, Dietary advice and practice. In: Unilever. The healthy choice, an easy choice, Vlaardingen, The Netherlands: Unilever Health Institute, p 43-46.

Labadarios, D., Swart, R., Maunder E.M.W., Kruger, H.S., Gericke, G.J., Kuzwayo, P.M.N., Ntsie, P.R., Steyn, N.P., Schloss, I., Dhansay, M.A., Jooste, P.L. \& Dannhauser, A., 2008, 'Executive summary of the National Food Consumption Survey Fortification Baseline (NFCS-FB-1) South Africa, 2005', South African Journal of Clinical Baseline (NFCS-FB-1) South Africa,
Nutrition 21(3)(Suppl. 2), 245-300.

Lee, M, McDonnell, E. \& Probart, C., 1998, 'Educators' nutrition knowledge, attitudes and perceptions of an interdisciplinary nutrition curriculum for grades K-6', Journal of Nutrition Education and Behaviour 98(9), A42.

Lumeng, J.C., Kaplan-Saroff, M., Shurman, S.\& Kannan, S., 2008, 'Head Start teachers' perceptions of children's eating behavior and weight status in the context of food scarcity', Journal of Nutrition Education and Behaviour 40(4), 37-243.

Marks, R., 2009, 'Schools and health education. What works, what is needed, and why?' Health Education 109(1), 4-8. http://dx.doi.org/10.1108/09654280910923345

Myers, L.A. \& Pope, J.F., 2009 'Nutrition, food and wellness: rationale and resources for implementation in family and consumer sciences teacher preparation programs', Journal of Family and Consumer Science Education 27(National Teacher Standards 4) 13-29.

Oldewage-Theron W.H. \& Egal, A.A., 2009, 'The evaluation of a nutrition education programme on the nutrition knowledge of children six to seven years old', Journa of Family Ecology and Consumer Sciences 37,45-51, viewed 14, February 2011 from http://ajol.info/index.php/jfecs/article/view/48945.

Roberts, S.M., Pobocik, R.S., Deek, R., Besgrove A. \& Prostine, B.A., 2009, 'A qualitative study of junior high school principals' and school food service directors' experiences with the Texas school nutrition policy', Journal of Nutrition Education and Behaviour 41(4), 293-299.

Shah, M., Adams-Huet, B., Elston, E., Hubbard, S. \& Carson, K., 2010, 'Food serving size knowledge in African American women and the relationship with body mass index', Journal of Nutrition Education and Behaviour 42(2), 9-105.

Sharma, S.V., Gernand, A.D. \& Day, R.S., 2008, 'Nutrition knowledge predicts eating behaviour of all food groups except fruits and vegetables among adults in the Paso del Norte region: Que Sabrosa Vida', Journal of Nutrition Education and Behaviour 40(6), 361-368.

Tessier, S., Chauliac, M. \& Latcha, B.D., 2010 'Nutrition education in schools: evaluation of a teaching method', Sante Publique 22(2), 229-238. PMid:20598189

Vorster, H., Love, P. \& Browne, C., 2001, 'Development of food-based dietary guidelines for South Africa - the process', South African Journal of Clinical Nutrition 14(Suppl 3), S3-S6.

Yokota, R.T.d.C., De Vasconcelos, Y.T.F., Pine, A.R.d.O., Schmitz, B.d.A.S., Coitinho, DC \& Rodrigues, M.d.L.C.F., 2010, 'Promotion of healthy eating habits by schools: \& Rodrigues, M.d.L.C.F., 2010, Promotion of healthy eating habits by schools:
comparison of two nutrition education strategies in the Federal District of Brazil. Journal of Nutrition 23(1):4-7. 